кандидат социологических наук, доцент, доцент кафедры общетеоретических правовых дисциплин

Северо-Кавказского филиала Российского

государственного университета правосудия

\section{ПРОБЛЕМА ФОРМИРОВАНИЯ ЭТНОКУЛЬТУРНОЙ ТОЛЕРАНТНОСТИ В ВУЗЕ (ОПЫТ СОЦИОЛОГИЧЕСКОГО ИССЛЕДОВАНИЯ)}

\section{Аннотация}

В статье рассматривается проблема этнокультурной толерантности в вузе. На основе результатов социологического исследования делается вывод о необходимости разработки иеленаправленных способов формирования этнокультурной толерантности в среде студенческой молодежи полиэтничного региона. Актуализируется значение социокультурного диалога как эффективной формы коммуникации и профилактики негативных проявлений интолерантности.

Ключевые слова:

этнокультурная толерантность, толерантность, полиэтничный регион, естественно-правовые ценности, интолерантность, социализация, социокультурный диалог.
PhD in Social Science, Assistant Professor, General Theoretical Legal Disciplines Department North Caucasus branch of Russian University of Justice

THE PROBLEM OF ETHNO-CULTURAL TOLERANCE DEVELOPMENT IN THE UNIVERSITY (SOCIOLOGICAL STUDY)

Summary:

The article deals with ethnic and cultural tolerance in higher school. Based on the results of the sociological study it is concluded that there is a need to develop targeted methods of students' ethnic and cultural tolerance development in the multiethnic region. The author emphasizes the value of the socio-cultural dialogue as an effective form of communication and prevention of negative manifestations of intolerance.

Keywords: ethno-cultural tolerance, tolerance, multiethnic region, natural law values, intolerance, socialization, socio-cultural dialogue.

В настоящее время в условиях нарастающего процесса глобализации и социокультурной интеграции неизбежно повышается уровень конфликтности как внутри государства, так и в международных отношениях. При этом возрастает необходимость сохранения мультикультурности как ориентации на самобытность и этнокультурную уникальность, что осуществить без прочных толерантных установок среди населения не представляется возможным.

Духовно-нравственные, религиозные, этнокультурные ценности не конструируются искусственно в процессе социализации, а встраиваются уже в готовом виде в этническую культуру. Таким образом, признавая сопричастность к этнической общности, личность принимает ее ценности и нормы такими, как они есть. В результате перед студенческой молодежью полиэтничного региона, а также администрацией вуза стоят серьезные проблемы, связанные с необходимостью постоянного целенаправленного воздействия на межличностные и групповые отношения в целях регулирования этнокультурных конфликтов.

Проблема этнокультурной толерантности как фрактора безопасности и социального прогресса всегда вызывала большой интерес и становилась предметом анализа в социально-философских, социологических, политико-правовых трудах дореволюционных авторов - Н.А. Бердяева, К.Н. Леонтьева, Вл. Соловьева, М.М. Ковалевского и др., советских ученых - Э.А. Баграмова, Э.В. Тадевосяна и др. В настоящее время вопросам динамики процессов толерантности и интолерантности в современном российском обществе уделяется внимание в исследованиях С.А. Арутюнова, А.Г. Здравомыслова, М.К. Горшкова и др. Значительный вклад в решение задачи формирования этнокультурной толерантности среди молодежи и рассмотрению проблемы восприятия ею представителей других национальностей внесен А.Г. Асмоловым, Е.В. Бондаревской, Т.С. Назаровой и др.

В исследованиях некоторых современных ученых успешно подтверждались или опровергались сложившиеся в общественном сознании «мифы» о восприятии русскими людьми представителей других национальностей. Так, А.Г. Здравомыслов, проведя анализ данных крупномасштабных социологических опросов наших соотечественников, пришел к выводу, что бытующие представления о возрастании национальной предвзятости и этноцентричности самосознания русских не соответствуют действительности [1, с. 23-32; 2, с. 15, 221].

В 2006 г. Институт социологии РАН при поддержке Департамента образования г. Москвы провел социологическое исследование по проблеме толерантности среди подростков в рамках 
проекта «Подростки и юношество в многонациональной Москве: фрормирование этнического самосознания и межэтнических отношений». Опрошены 2455 учеников средних образовательных школ Москвы, среди которых были и учреждения с этнокультурным компонентом (русским, азербайджанским, армянским, грузинским, еврейским, корейским, татарским). Анализ показал, что для большинства подростков большое значение имеет собственная национальность, а отношение к людям и выбор друзей не зависят от национальности, при этом «своя» нация не считается лучше или хуже других.

Однако исследователи обратили внимание, что, несмотря на положительные ответы, среди внешкольных друзей преобладают люди «своей» национальности, а также при разрешении национальных конфликтов школьники отдают предпочтение представителям собственного народа/этноса. Кроме того, по мнению респондентов, в нашей стране не все народы имеют равные социальные возможности (хотя Конституция РФ и ее законы предусматривают равенство для всех граждан вне зависимости от их этнической принадлежности). Так, большинство подростков (75 \%) высказались за ужесточение наказания за разжигание межнациональной розни и распространение нацистских идей. В целом опрос выявил средний уровень толерантности среди школьников и необходимость серьезного осмысления этой проблемы на уровне государства [3; 4, с. 335-360].

Проблема этнокультурной толерантности приобретает особое значение для общественной безопасности и развития культурных традиций в полиэтничном регионе, каким является Краснодарский край. В связи с этим необходимо обратиться к некоторым результатам проведенного нами в рамках работы социологической лаборатории Северо-Кавказского филиала Российского государственного университета правосудия (бывшей Российской академии правосудия) в 2010 г. исследования по названной проблематике. В опросе (анкетировании) приняли участие 302 студента очной фрормы обучения юридического фракультета. Перед нами стояли следующие задачи:

- определить значение для респондентов собственной национальности;

- выявить, с чем опрошенные связывают единство национальности;

- выяснить, что нравится студентам в общении с представителями других национальностей;

- установить степень заинтересованности респондентов в мероприятиях, направленных на фрормирование толерантного сознания в студенческой среде;

- систематизировать предложения по повышению уровня толерантности, выдвинутые самими опрашиваемыми.

Вопросы в анкете были выстроены в соответствии с поставленными задачами. В ответе на вопрос, имеет ли для студентов значение их собственная национальность, выявлена следующая закономерность: чем старше респонденты и чем ближе они к выпускному курсу, тем важнее для них собственная национальность. Соответственно, количество тех, для кого национальность не имеет значения, снижается к старшим курсам. Если число респондентов на первом курсе составляло 36 \%, то к окончанию вуза оно снижается до 13 \%. Также доля тех, кто не задумывался о значении собственной национальности, сокращается с 15 до 2 \% к третьему курсу, а на четвертом и пятом подобные мнения отсутствуют вовсе. Таким образом, все без исключения респонденты выпускных курсов осознают важность собственной национальности (таблица 1).

Таблица 1 - Мнение студентов о том, имеет ли значение для них собственная национальность, \%

\begin{tabular}{|c|c|c|c|}
\hline Курс обучения / вариант ответа & Имеет & Не имеет & Не думал об этом \\
\hline 1 & 49 & 36 & 15 \\
\hline 2 & 58 & 36 & 6 \\
\hline 3 & 79 & 19 & 2 \\
\hline 4 & 65 & 35 & - \\
\hline 5 & 87 & 13 & - \\
\hline
\end{tabular}

Период студенчества - оптимальное время для социализации личности и формирования толерантности. На данном этапе основные ценности и нормы уже усвоены, обостряется процесс самопознания, самовоспитания и самообучения, расширяются социальные связи, возрастают роль и ответственность агентов социализации - преподавателей, администрации вуза, города, СМИ и др. Их особые усилия должны быть направлены на развитие толерантности в трех направлениях - личном, общественном и общегосударственном. При этом мероприятия, содействующие повышению уровня толерантности, не могут проводиться в отрыве от повышения общекультурного уровня развития личности. Доказательством этой мысли являются ответы студентов на вопрос о том, с чем они связывают единство национальности. Большинство опрошенных отметили, что для них это прежде всего «общность культурных традиций», затем - «единая религия», «единство языка», в последнюю очередь - «отметка в паспорте».

На вопрос о том, что нравится студентам в общении с представителями других национальностей, выбор респондентов распределился между такими вариантами, как «возможность познакомиться с культурными, нравственными ценностями других национальностей», «расширение 
кругозора», «возможность быстро выучить язык». В открытом варианте ответа опрошенные высказали в основном толерантные мнения, базирующиеся на естественно-правовых ценностях, гуманизме и космополитизме. Среди них наиболее распространенными являются следующие ответы: «для меня вообще национальность значения не имеет, главное - чтобы человек был хороший», «среди представителей разных национальностей встречаются умные, интересные и порядочные люди», «люди других национальностей уже интересны для меня тем, что не похожи на меня», «нам всегда есть чему поучиться друг у друга», «все люди равны от природы», «главное человеческие качества, а не национальность». Важно, что доля респондентов, имеющих установки на продуктивное взаимодействие с представителями других национальностей, увеличивается по мере взросления и профессионального становления (от 14 до 26 \%) (таблица 2).

Таблица 2 - Мнение студентов о том, что им нравится в общении с представителями других национальностей, \%

\begin{tabular}{|c|c|c|c|c|}
\hline $\begin{array}{c}\text { Курс обучения / } \\
\text { вариант ответа }\end{array}$ & $\begin{array}{c}\text { Можно быстро } \\
\text { выучить } \\
\text { другой язык }\end{array}$ & $\begin{array}{c}\text { Можно познакомиться } \\
\text { с культурными, } \\
\text { нравственными ценностями }\end{array}$ & $\begin{array}{c}\text { Это расширяет } \\
\text { мой кругозор }\end{array}$ & $\begin{array}{c}\text { Свой } \\
\text { вариант }\end{array}$ \\
\hline 1 & 2 & 33 & 51 & 14 \\
\hline 2 & 2 & 41 & 36 & 21 \\
\hline 3 & 5 & 39 & 37 & 19 \\
\hline 4 & 2 & 31 & 40 & 27 \\
\hline 5 & 0 & 26 & 48 & 26 \\
\hline
\end{tabular}

Следует отметить, что студенты вуза полиэтничного региона, в частности Краснодарского края, вполне отчетливо осознают, что возникающие явления интолерантности нельзя оставлять без разрешения, что они во многом определяют качественное состояние социокультурной реальности, в которой проходят личностное становление и формирование сознания студенческой молодежи.

Так, на вопрос о необходимости проведения мероприятий по повышению уровня толерантности, степени сплочения студенческого коллектива большинство респондентов ответили утвердительно. Мы выявили следующую тенденцию: количество сторонников использования подобных средств возрастает по мере их взросления - от первого к выпускному курсу (от 55 до 74 \%). В качестве обоснования собственной позиции приводились следующие аргументы: «в нашем вузе учатся люди разных национальностей», «это поможет избежать конфликтов и установить благоприятную атмосферу не только в вузе, но и в обществе», «мы - будущие юристы, коллеги, поэтому должны уважать друг друга», «некоторые из нас станут судьями, а судьи должны быть толерантными», «мы устали от международных конфликтов и войн», «проблема есть, и ее надо как-то решать».

Немногочисленные респонденты, высказавшиеся за то, что такие мероприятия не нужны в вузе (доля респондентов повышается от 7 до $15 \%$ к третьему курсу и затем снова снижается с 15 до 9 \% к выпускному курсу), обосновали свою позицию тем, что «национальную терпимость нужно воспитывать с детства», «бесполезно учить человека терпимости, если он сам к этому не стремится», «подобную проблему не решить в вузе, а только на государственном уровне», «с национализмом и шовинизмом вообще трудно справиться». Проанализировав содержание изложенных мнений, следует заметить, что в них присутствует не столько категоричный отказ от мероприятий, направленных на повышение уровня толерантности в студенческой среде, а некоторый пессимизм по поводу возможности полного разрешения столь древней проблемы и, как следствие, уверенность в необходимости системного подхода к ее профилактике и преодолению, начиная с детства. Важно также обратить внимание на то, что доля респондентов, не задумывавшихся о необходимости мероприятий, направленных на сплочение представителей национальностей в вузе, снижается к пятому курсу. Так, если на первом курсе их количество составляло $38 \%$, то на пятом - $21 \%$ (таблица 3 ).

Таблица 3 - Мнение студентов о необходимости проведения в вузе мероприятий, направленных на сплочение представителей разных национальностей, \%

\begin{tabular}{|c|c|c|c|}
\hline $\begin{array}{c}\text { Курс обучения / } \\
\text { вариант ответа }\end{array}$ & Нужно, потому что... & Не нужно, потому что... & Не думал об этом \\
\hline 1 & 55 & 7 & 38 \\
\hline 2 & 74 & 9 & 17 \\
\hline 3 & 65 & 15 & 20 \\
\hline 4 & 58 & 9 & 33 \\
\hline 5 & 70 & 9 & 21 \\
\hline
\end{tabular}

На вопрос о том, какие именно меры, по мнению студентов, будут способствовать сплочению представителей разных национальностей, получено немало интересных ответов. Мы разделили их на следующие типовые группы: совместные внеаудиторные мероприятия, посвященные 
нейтральным (общекультурным) темам, отвлекающие от межнациональных проблем; праздничные мероприятия, знакомящие с особенностями национальных культур; любые совместные мероприятия без соревновательного элемента; активизация работы психолога в вузе [5, с. 14-15].

Подводя итог изложенному, следует обратить внимание на то, что студенты - будущие юристы увидели способы разрешения проблемы не в нормативном регулировании отношений между представителями разных этнических групп, но в метаюридической реальности, в области межкультурной коммуникации, в частности - посредством социокультурного диалога. Как представляется, именно в этом диалоге выражается потенциал процесса социализации в вузе, одним из важных направлений которого является фрормирование установок на толерантное поведение, на стремление к компромиссу, обмену культурными ценностями между студентами. Несмотря на то что в настоящее время не теряют актуальности учебные социально-гуманитарные дисциплины, базирующиеся на аксиологической «платформе», системное решение проблемы формирования толерантности возможно в комплексе аудиторной и внеаудиторной работы.

Социокультурный диалог как основа разных форм внеаудиторных мероприятий, предложенных самими студентами, как способ формирования этнокультурной толерантности способствует разрешению многих серьезных проблем и выполнению следующих задач, стоящих перед вузом в полиэтничном регионе:

- развитие интереса к собственной культуре и культуре представителей народов, обучающихся в вузе;

- создание условий и навыков социокультурного диалога;

- борьба с имеющимися проявлениями ксенофобии, национализма, шовинизма, экстремизма в среде студенческой молодежи, а также профилактика этих явлений в будущем.

\section{Ссылки:}

1. Здравомыслов А.Г. Этнополитические процессы и динамика национального самосознания россиян // Социологические исследования. 1996. № 12.

2. Россия: центр и регионы. Вып. 4 / под ред. М.С. Гуцериева, В.Н. Иванова. М., 1999

3. Добрынина Е. Тройка по толерантности // Российская газета. 2007. 22 марта.

4. Свобода. Неравенство. Братство: Социологический портрет современной России / под ред. М.К. Горшкова. М., 2007. $448 \mathrm{c.}$.

5. Подробнее см.: Гусарова М.А. Проблема национальной терпимости в среде будущих специалистов для судебной системы (опыт социологического исследования) // Судебные ведомости. 2011. Вып. 3 (37). С. 10-15.

\section{References:} sian).

Gorshkov, MK (ed.) 2007, Liberty, equality and fraternity: Sociological portrait of modern Russia, Moscow, 448 p., (in Rus-

Gusarova, MA 2011, 'The problem of national tolerance among future specialists for the judiciary system (the experience of sociological research)', Sudebnyye vedomosti, Issue 3 (37), pp. 10-15, (in Russian).

Gutseriev, MS \& Ivanov, VN (eds.) 1999, Russia: the center and the regions, Issue 4, (in Russian).

Dobrynina, E 2007, 'Satisfactory mark in Tolerance', Rossiyskaya Gazeta, March 22, (in Russian).

Zdravomyslov, AG 1996, 'Ethnopolitical processes and dynamics of national consciousness of Russians', Sotsiologicheskiye issledovaniya, no. 12, (in Russian). 